\title{
Is marketing communication really a challenge for companies on Instagram?
}

\author{
Kamilla Sánta ${ }^{1, *}$, Patrik Baša ${ }^{2}$, and Renáta Machová ${ }^{3}$ \\ ${ }^{1}$ student, J. Selye University, Faculty of Economics and Informatics, Bratislavská cesta 3322, 94501 \\ Komárno, Slovakia \\ ${ }^{2}$ student, J. Selye University, Faculty of Economics and Informatics, Bratislavská cesta 3322, 94501 \\ Komárno, Slovakia \\ ${ }^{3}$ Management Department, J. Selye University, Faculty of Economics and Informatics, Bratislavská \\ cesta 3322, 94501 Komárno, Slovakia
}

\begin{abstract}
Meeting the challenges of social media is becoming more and more important for companies in the $21^{\text {st }}$ century. If companies want to be successful, they need to be present not only in the real world but also in the virtual world. With this paper, we would like to help companies in their marketing communication on Instagram. We carried out an international research on the most important factors of Instagram business profile and examined their relationship by correlation analysis. Our results are summarized in a model, which includes several factors that companies must simultaneously consider when following a particular social media strategy. Since we have not discovered big differences among the countries we examined, our model could have been used internationally (primarily by Central European companies).
\end{abstract}

\section{Introduction}

As we move forward in the $21^{\text {st }}$ century, it is becoming increasingly important for companies to meet the challenges of social media, as it is one of the simplest and perhaps the most effective channels for building relationships with consumers. Companies need to be present and build their brand in the real world, but also in the virtual world. In the first chapter of the paper, we deal with social media and Instagram on a theoretical level. After that we write down our results and demonstrate our model.

\subsection{Social media}

According to Kaplan and Haenlein the social media "is a group of Internet-based applications that build on the ideological and technological foundations of Web 2.0, and allow the creation and exchange of user-generated content" [1]. Van der Heide and Lim described social media as an environment where anyone can say anything about anything to everyone. [2] An important unique characteristic of social media is networking capability, which is also one of

\footnotetext{
*Corresponding author: 122111@student.ujs.sk
} 
the most capitalized benefits of it. Consumers are partly in control of how information is created and shared. [3] Social media also differ from other media in the way in which they are experienced, such as satisfying the need to find useful information, filling empty moments, or creating or sharing content with others. [4] Social media are unique with regard to the massive amounts of data they provide. The data provided by social media platforms have great potential to examine and explain consumers' interactions and responses to brand communication in social media in a natural setting. [5]

Social media and television are major influencers when it comes to the purchasing decisions of consumers. The products of tens of thousands of companies entice consumers through various channels, which creates the artificial generation of consumer needs. There have also been changes in the human perception: people measure everything in money, they always want to dress in the latest fashion, call their friends on the newest mobile phones and post about these things on social media. These facts represent a huge opportunity for marketers and offer a virtual marketplace for companies to sell their products. [6]

The forms of social media are the following: social networking sites, creativity works sharing sites (video, photo, music, content, general intellectual property), user-sponsored blogs, company-sponsored websites/blogs, company-sponsored cause/help sites, invitationonly social networks, business networking sites, collaborative websites, virtual worlds, commerce communities, podcasts, news delivery sites, educational materials sharing, open source software communities, social bookmarking sites allowing users to recommend online news stories, music, videos, etc. These media have become a major factor in influencing various aspects of consumer behaviour including awareness, information acquisition, opinions, attitudes, purchase behaviour, and post-purchase communication and evaluation. [7]

Social networking sites are probably the most prominent type of social media. [8] The number of these platforms grows rapidly, as new applications spring up almost every day. [9]

\subsection{Instagram and business profile}

The strength of social ties plays an important role in consumer responses to brand communication via social media. [10] Brands often use native advertising formats on social media. [11] The message on social media does not necessarily refer to what is being said by the brand, it also refers to User Generated Content. Professionals often use the term content rather than message. [5]

Instagram, a mobile photo and video capturing and sharing application, has quickly emerged as a new medium in spotlight in the recent years. It provides users an instantaneous way to capture and share their life moments with friends through a series of pictures and videos. [12] In the past few years Instagram is getting popular among companies. Nowadays users and companies can switch their personal profile to business profile and take advantage of it on the field of marketing.

Instagram's business profile promises a number of new opportunities for companies. They can view analyzes, provide contact information and specify the price of the products in the photos. Later \& HubSpot's e-book details what companies need to pay attention when creating the profile:

- name - user name on Instagram (mostly the name of the company)

- description - a concise but comprehensive description of the company's activity

- keywords - the values represented by the company

- $\quad$ link to website - placing the link to the website of the company

- own hashtags - using the company name and product names in the form of a hashtag

- call to action - encouraging followers to take action on the companie's profile [13] 
As more and more companies appeared on Instagram, traces of their marketing activities became more and more noticeable. The three most common marketing tools for companies on Instagram are:

- Giveaways - the most common and simplest form of giveaways is based on the "like and comment" principle. As the name implies, the user has to like a photo or video posted by the company and write a comment. Recently, it has become more and more common to tag some friends in the comment, so they can also participate. The prize of the giveaway is usually a product of the company.

- Influencer-marketing - In every social group, there are people who are better informed than others or express their opinions more often than other members of the group. Because most people are unable, or unwilling, to provide relevant information on a topic, they accept the information shared by those individuals and believe it is trustworthy. [14] Influencers are now the basis of marketing activities in social media.

- Paid Advertising - Within the classic Instagram ads, we know four basic categories that differ in the way they are displayed. This includes advertising by image, story, video, or carousel.

Instagram is a valuable tool for companies who want to get their brand known. [15]

\section{Methodology}

The research was realised between February 2019 and February 2020. Our questionnaire was prepared online and sent to Slovak Instagram users via social media. People, who filled in the questionnaire were asked to send it to another five Instagram users. In order to obtain answers from another countries, we contacted the partner institutions of the J. Selye University. Thanks to it, we got answers from Hungary and Romania. A total of 754 evaluable responses were received to the questionnaire prepared in Hungarian and English language. Responses were coded in Microsoft Excel and analysed in SPSS statistical software. To test our four hypotheses, we performed correlation analysis. After the analysis, we created a model that includes the relationship of factors belonging to the same group.

\section{Results}

As mentioned above, a total of 754 evaluable responses were received to our online questionnaire - 242 from Slovakia, 332 from Hungary and 180 from Romania. In terms of gender, $66,31 \%$ of the respondents were women and $33,69 \%$ are men.

Our questionnaire was filled in by the representatives of the 18-24 age group in the highest proportion $(75,73 \%)$, followed by the $25-34$ age group $(15,65 \%)$, by the $35-44$ age group $(3,85 \%)$, by the $45-54$ age group $(1,99 \%)$, by those over $55(1,46 \%)$, and finally those under $18(1,33 \%)$.

Our research was based on a series of questions measured on a Likert scale containing 13 factors. Respondents had to decide how important (1-not important at all, 5-very important) a factor was for them on a company's business profile.

Table 1. Means of factors of Instagram business profile

\begin{tabular}{|l|c|c|c|}
\hline & Slovakia & Hungary & Romania \\
\hline High number of followers & 2,281 & 2,130 & 2,106 \\
\hline Good profile picture & 2,508 & 2,539 & 2,517 \\
\hline Comprehensive description of the company & 2,901 & 2,883 & 2,750 \\
\hline Regular posting & 2,938 & 3,123 & 2,694 \\
\hline
\end{tabular}




\begin{tabular}{|l|c|c|c|}
\hline Sharing costumer photos & 2,707 & 2,726 & 2,433 \\
\hline Consistency of images & 2,583 & 2,873 & 2,572 \\
\hline Creative descriptions of pictures & 2,781 & 2,946 & 2,722 \\
\hline Placing link to the website & 2,967 & 3,120 & 2,789 \\
\hline Ordering option in message & 2,517 & 2,413 & 2,444 \\
\hline Indication of the price & 2,955 & 3,060 & 2,900 \\
\hline Regular Story & 2,227 & 2,202 & 2,061 \\
\hline Giveaways & 2,380 & 2,419 & 2,250 \\
\hline Collaborate with famous people & 2,475 & 2,304 & 2,417 \\
\hline
\end{tabular}

There are no major differences between the three countries, but minor differences can be noticed. Based on the means of the individual factors, Instagram users in Slovakia consider the placement of a link to the corporate website, the indication of the price of the product, the regular posting and a comprehensive description of the corporate activity to be the most important. For the Hungarian respondents, the most important factor of the business profile is the regular posting, followed by the placement of a link to the company's website, the indication of the price of the product and the creative description of the uploaded images. In the case of Romania, the most important factors are the indication of the price of the product, the placement of a link to the company's website, a comprehensive description of the company's activities and a creative description of the uploaded images. Instagram users in all three countries consider regular Story sharing and a high number of followers to be the least important factors.

In our research four hypotheses were formulated. When examining the hypotheses, we performed correlation analysis, as each intervale-scale variable was measured on a metric scale. In the course of correlation analysis, we can get an answer to the question of whether there is a relationship between the examined quantitative variables and, if so, how close it is. The closer the absolute value of Pearson's correlation coefficient (r) is to 1 , the closer the relationship. According to Sajtos-Mitev's [16] SPSS data analysis manual, if $|0,2|<\mathrm{r}<|0,7|$, the relationship is moderately strong, and if $|0.7|<\mathrm{r}<|1|$, the relationship is strong.

In the analysis of the first hypothesis, we examined the relationship between "creative factors" related to the business profile.

Table 2. Correlation analysis - Creative factors

\begin{tabular}{|c|c|c|c|c|c|}
\hline & & $\begin{array}{l}\text { Good } \\
\text { profile } \\
\text { picture }\end{array}$ & $\begin{array}{c}\text { Comprehensi } \\
\text { ve description } \\
\text { of the } \\
\text { company }\end{array}$ & $\begin{array}{l}\text { Consiste } \\
\text { ncy of } \\
\text { images }\end{array}$ & $\begin{array}{l}\text { Creative } \\
\text { description } \\
\mathrm{s} \text { for the } \\
\text { pictures }\end{array}$ \\
\hline \multirow{3}{*}{$\begin{array}{l}\text { Good profile } \\
\text { picture }\end{array}$} & Pearson Corr. & 1 &, $5_{18}^{* *}$ &, $268^{* *}$ &, $\mathbf{2 8 0}^{* *}$ \\
\hline & Sig. (2-tailed) & &, 000 &, 000 &, 000 \\
\hline & $\mathrm{N}$ & 754 & 754 & 754 & 754 \\
\hline \multirow{3}{*}{$\begin{array}{l}\text { A comprehensive } \\
\text { description of the } \\
\text { company }\end{array}$} & Pearson Corr. &, $518^{* *}$ & 1 &, $306^{* *}$ &, $430^{* *}$ \\
\hline & Sig. (2-tailed) &, 000 & &, 000 &, 000 \\
\hline & $\mathrm{N}$ & 754 & 754 & 754 & 754 \\
\hline \multirow{3}{*}{$\begin{array}{l}\text { Consistency of } \\
\text { images }\end{array}$} & Pearson Corr. &, $268^{* *}$ &, $306^{* *}$ & 1 &, $526^{* *}$ \\
\hline & Sig. (2-tailed) &, 000 &, 000 & &, 000 \\
\hline & $\mathrm{N}$ & 754 & 754 & 754 & 754 \\
\hline \multirow{3}{*}{$\begin{array}{l}\text { Creative } \\
\text { descriptions for } \\
\text { the pictures }\end{array}$} & Pearson Corr. &, $280^{* *}$ &, $430^{* *}$ &, $526^{* *}$ & 1 \\
\hline & Sig. (2-tailed) &, 000 &, 000 &, 000 & \\
\hline & $\mathrm{N}$ & 754 & 754 & 754 & 754 \\
\hline
\end{tabular}


We identified as "contact factors" the factors that target keeping in touch with followers, customers, and influencers.

Table 3. Correlation analysis - Contact factors

\begin{tabular}{|c|c|c|c|c|c|}
\hline & & $\begin{array}{c}\text { High } \\
\text { number of } \\
\text { followers }\end{array}$ & $\begin{array}{c}\text { Share } \\
\text { customer } \\
\text { photos }\end{array}$ & $\begin{array}{c}\text { Giveawa } \\
\text { ys }\end{array}$ & \begin{tabular}{|c} 
Collaborate \\
with famous \\
people
\end{tabular} \\
\hline \multirow{3}{*}{$\begin{array}{l}\text { High number of } \\
\text { followers }\end{array}$} & Pearson Corr. & 1 &, $235^{* *}$ &, $229^{* *}$ & $\begin{array}{r}, 371^{* *} \\
\end{array}$ \\
\hline & Sig. (2-tailed) & &, 000 &, 000 &, 000 \\
\hline & $\mathrm{N}$ & 754 & 754 & 754 & 754 \\
\hline \multirow{3}{*}{$\begin{array}{l}\text { Share customer } \\
\text { photos }\end{array}$} & Pearson Corr. & $235^{* *}$ & 1 &, $\mathbf{3 8 5}^{* *}$ &, $\mathbf{3 1 1}^{* *}$ \\
\hline & Sig. (2-tailed) &, 000 & &, 000 &, 000 \\
\hline & $\mathrm{N}$ & 754 & 754 & 754 & 754 \\
\hline \multirow{3}{*}{$\begin{array}{l}\text { Launch } \\
\text { giveaways }\end{array}$} & Pearson Corr. & $229^{* *}$ &, $385^{* *}$ & 1 &, $467^{* *}$ \\
\hline & Sig. (2-tailed) &, 000 &, 000 & &, 000 \\
\hline & $\mathrm{N}$ & 754 & 754 & 754 & 754 \\
\hline \multirow{3}{*}{$\begin{array}{l}\text { Collaborate with } \\
\text { famous people }\end{array}$} & Pearson Corr. &, $371^{* *}$ &, $311^{* *}$ &, $467^{* *}$ & 1 \\
\hline & Sig. (2-tailed) &, 000 &, 000 &, 000 & \\
\hline & $\mathrm{N}$ & 754 & 754 & 754 & 754 \\
\hline
\end{tabular}

"Business factors" included factors that were closely related to the purchase of products and the use of services.

Table 4. Correlation analysis - Business factors

\begin{tabular}{|l|l|r|r|r|}
\hline \multicolumn{2}{|c|}{} & \multicolumn{1}{|c|}{$\begin{array}{c}\text { Placing a } \\
\text { link to the } \\
\text { website }\end{array}$} & $\begin{array}{c}\text { Indication of } \\
\text { the price of } \\
\text { the product }\end{array}$ & $\begin{array}{c}\text { Order } \\
\text { option in } \\
\text { message }\end{array}$ \\
\hline $\begin{array}{l}\text { Placing a link to } \\
\text { the corporation's } \\
\text { website }\end{array}$ & Pearson Corr. & 1 & $\mathbf{4 4 9}^{* *}$ & $\mathbf{4 4 9}^{* *}$ \\
\cline { 2 - 5 } & Sig. (2-tailed) & &, 000 &, 000 \\
\cline { 2 - 5 } & $\mathrm{N}$ & 754 & 754 & 754 \\
\hline \multirow{2}{*}{$\begin{array}{l}\text { Indication of the } \\
\text { price of the } \\
\text { product }\end{array}$} & Pearson Corr. &, $449^{* *}$ & 1 & $\mathbf{4 1 6}^{* *}$ \\
\cline { 2 - 5 } & Sig. (2-tailed) &, 000 & &, 000 \\
\cline { 2 - 6 } $\begin{array}{l}\text { Order option in } \\
\text { message }\end{array}$ & Pearson Corr. &, $449^{* *}$ &, $416^{* *}$ & 754 \\
\cline { 2 - 6 } & Sig. (2-tailed) &, 000 &, 000 & 1 \\
\cline { 2 - 6 } & $\mathrm{N}$ & 754 & 754 & 754 \\
\hline
\end{tabular}

"General factors" included regular posting and regular Story sharing.

Table 5. Correlation analysis - General factors

\begin{tabular}{|l|l|r|r|}
\hline \multicolumn{2}{|c|}{} & \multicolumn{1}{|c|}{$\begin{array}{c}\text { Regular } \\
\text { posting }\end{array}$} & $\begin{array}{c}\text { Regular Story } \\
\text { Sharing }\end{array}$ \\
\hline \multirow{2}{*}{$\begin{array}{l}\text { Regular } \\
\text { posting }\end{array}$} & Pearson Corr. & 1 &, $\mathbf{3 6 7}^{* *}$ \\
\cline { 2 - 4 } & Sig. (2-tailed) & &, 000 \\
\cline { 2 - 4 } & $\mathrm{N}$ & 754 & 754 \\
\hline \multirow{2}{*}{$\begin{array}{l}\text { Regular Story } \\
\text { Sharing }\end{array}$} & Pearson Corr. &, $367^{* *}$ & 1 \\
\cline { 2 - 4 } & Sig. (2-tailed) &, 000 & \\
\cline { 2 - 4 } & $\mathrm{N}$ & 754 & 754 \\
\hline
\end{tabular}


A significant result was obtained when analyzing the factors, as $r>0,2$ in all cases. The relationship is positive in all cases and moderately strong. Hypotheses H1, H2, H3, and H4 were accepted and null hypotheses were discarded.

Since all hypotheses were accepted, we could have created the relationship model of the factors belonging to the four groups:

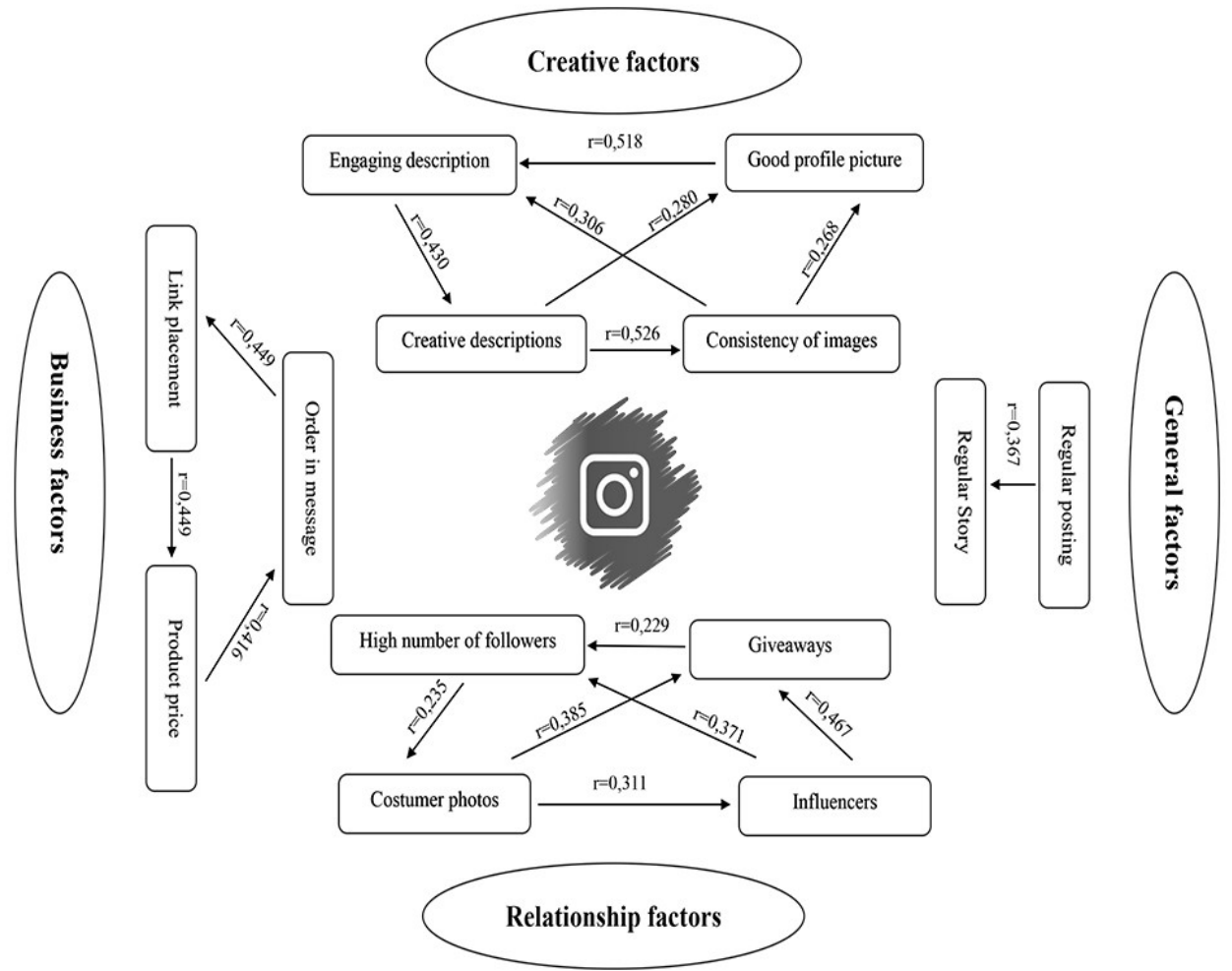

Fig. 1. The model of the most important factors on Instagram business profile

If a particular factor is considered important by the followers of the company, with our model the companies can already know which other factors are also important to these consumers. Based on the model, companies can develop their Instagram marketing strategy and focus on the factors of that strategy (creative, relationship, business and general).

We also examined whether there is a difference between the means of responses in Slovakia, Hungary and Romania, but since the difference is minimal, the model can be applied internationally by companies operating (primarily) in Central Europe.

\section{Discussions}

Marketing communication on social media is no longer such a challenge for companies. The model we have created allows the companies to choose a type of strategy they want to focus on in their marketing communication. It is the responsibility of companies that focus on creative factors to focus on the visual elements of the business profile: have a good profile picture, have visually consistent photos, have compelling description of the company's activities and write creative descriptions under the uploaded photos. In a relationship-based strategy, the company needs to build the highest possible follower base, share customer images on a regular basis, collaborate with well-known people (influencer marketing) and 
organize giveaways. The essence of the strategy focusing on business factors is to place a link to the company website, to ensure the possibility of ordering via private message and to indicate the price of the products on pictures. Companies that use the strategy of general factors related should pay attention to regular posting and regular story sharing. The four groups (strategies) do not mean that a company can use only one of them, but it is recommended that the company select just one, and chooses another one once its activities related to those factors are working effectively. As we examined the responses of three countries and did not find big differences between the responses (means) in Slovakia, Hungary and Romania, the model can be applied internationally (primarily) in Central Europe.

This work was supported by the by the Collegium Talentum 2019 Programme of Hungary.

\section{References}

1. A. M. Kaplan, M. Haenlein, Users of the world, unite! The challenges and opportunities of social media. Business Horizons 53 59-68 (2010) DOI: 10.1016/j.bushor.2019.09.003

2. B. Van Der Heide, L. Young-Shin, On the conditional cueing of credibility heuristics: The case of online influence. Communication Research 43, 672 (2016) DOI: $10.1177 / 0093650214565915$

3. S. Okazaki, C.R. Taylor, Social media and international advertising: Theoretical challenges and future directions. International Marketing Review 30, 56-71 (2013) DOI: $10.1108 / 02651331311298573$

4. H.A.M. Voorveld, G. Van Noort, D.G. Muntinga, F. Bronner, Engagement with social media and social media advertising: The differentiating role of platform type. Journal of Advertising 47 38-54. (2018) DOI: 10.1080/00913367.2017.1405754

5. H.A.M Voorveld, Brand communication in social media: A research agenda. Journal of Advertising 48, 14-26 (2019) DOI: 10.1080/00913367.2019.1588808

6. L. Mura, D. Halasi, The marketing is the key factor? - Modern marketing elements are the keys of the corporate success. Selye E-studies 7 1-11 (2016)

7. W.G. Mangold, D.J. Faulds, Social media: The new hybrid element of the promotion mix. Business Horizons 52, 357-365 (2009) DOI: 10.1016/j.bushor.2009.03.002

8. D.H. Boyd, N.B. Ellison, Social network sites: Definition, history, and scholarship. Journal of Computer-Mediated Communication 13, 210-230 (2007) DOI: 10.1111/j.1083-6101.2007.00393.x

9. B.J. Phillips, J. Miller, E.F. McQuarrie, Dreaming out loud on Pinterest: New forms and indirect persuasion. International Journal of Advertising 33, 633-655 (2014) DOI: 10.2501/IJA-33-4-633-655

10. J.L. Hayes, Y. Shan, K. Whitehill King, The interconnected role of strength of brand and interpersonal relationships and user comment valence on brand video sharing behavior. International Journal of Advertising 37, 142-164 (2018) DOI: 10.1080/02650487.2017.1360576

11. S.C. Boerman, L.M. Willemsen, E.P. Van Der Aa, This post is sponsored: Effects of sponsorship disclosure on persuasion knowledge and electronic word of mouth in the context of Facebook. Journal of Interactive Marketing 38, 82-92 (2017) DOI: 10.1016/j.intmar.2016.12.002

12. Y. Hu, L. Manikonda, S. Kambhampati, What we Instagram: A first analysis of Instagram photo content and user types. Proceedings of the Eight International AAAI Conference on Weblogs and Social Media 595-598 (2014)

13. Later\&Hubspot, Instagram for business in 2018: Using Instagram stories, carousels, ads, influencers, and more. 4-22 (2018) 
14. R. Bačuvčík, L. Harántová, Sociálni marketing. (Vědecká redakce nakladatelství, Prague, 2016)

15. J.G. Miles, Instagram power: Build your brand and reach more customers with the power of pictures. (McGraw-Hill Education, New York, 2014)

16. L. Sajtos, A. Mitev, SPSS Kutatási és adatelemzési kézikönyv (Alinea Kiadó, Budapest, 2007) 